\title{
Awareness, knowledge and prevention of mother to child transmission of human immunodeficiency virus in pregnant women: a descriptive study
}

\author{
Monika Parmar, Rupa Aherwar*, Shashikala Jawade \\ Department of Obstetrics and Gynaecology, Chirayu Medical College, Bhopal, Madhya Pradesh, India
}

Received: 29 April 2016

Accepted: 02 June 2016

*Correspondence:

Dr. Rupa Aherwar,

E-mail: ahirwar.rupa@gmail.com

Copyright: ( $)$ the author(s), publisher and licensee Medip Academy. This is an open-access article distributed under the terms of the Creative Commons Attribution Non-Commercial License, which permits unrestricted non-commercial use, distribution, and reproduction in any medium, provided the original work is properly cited.

\section{ABSTRACT}

Background: India has the third highest number of estimated people living with HIV in the world. According to the HIV estimations 2012, the estimated number of people living with HIV/AIDS in India was 20.89 lakh, with an estimated adult (15-49 age group) HIV prevalence of $0.27 \%$ in 2011. The objective of this study was to evaluate the awareness and knowledge of mother-to-child transmission of HIV and its prevention among pregnant women attending the antenatal clinic.

Methods: A cross sectional descriptive study was carried out at the antenatal clinic of Chirayu medical college and hospital, Bhopal, Madhya Pradesh, India from August 2015 to January 2016. Antenatal clinics run with average total attendance of 40 per day. A pretested questionnaire was designed to assess awareness of the women about HIV/AIDS, evaluate their knowledge of possible routes of transmission-particularly mother to child transmission-and measures to prevent vertical transmission from mother to child.

Results: Amongst the respondents, $84 \%$ had heard of HIV and in $79 \%$ of them, the source of information was through mass media. 54.8\% were aware of sexual intercourse as a mode of transmission of HIV while $43 \%$ knew that sharing sharp objects and infected blood products can spread HIV. 66\% of respondents were aware of MTCT and $33.6 \%$ heard of antiretroviral therapy as a method of prevention of MTCT. $74 \%$ were aware of contracting infection by sexual contact with infected partner. Majority of them (77.4\%) were aware of increased risk of contracting HIV/AIDS by sexual relationship with multiple partners. $74 \%$ of females were aware that HIV/AIDS is preventable. $59.6 \%$ of women were aware of availability of ART of AIDS treatment. $72.5 \%$ of study population was aware that use of condom can protect against HIV transmission.

Conclusions: Although awareness of HIV and MTCT is increased as compared to previous studies, but to achieve global plan to reduce MTCT by $90 \%$ there is still need to promote programs targeting antenatal population with emphasis on MTCT and its various methods of prevention.

Keywords: HIV/AIDS, MTCT

\section{INTRODUCTION}

India has the third highest number of estimated people living with HIV in the world. According to the HIV Estimations 2012, the estimated number of people living with HIV/AIDS in India was 20.89 lakh, with an estimated adult (15-49 age group) HIV prevalence of
$0.27 \%$ in 2011. Of all HIV infections, 39\% (8.16 lakh) were among women. The estimated number of PLHIV in India has maintained a steady declining trend from 23.2 lakh in 2006 to 20.9 lakh in 2011. According to HSS 2012-2013, the overall HIV prevalence among ANC attendees continued to be low at $0.35 \%$ in the country, with an overall declining trend at the national level. The 
prevalence is highest among productive young people between the ages of 20-29 years, with $60 \%$ of new infections occurring in the 15-25 years old age group. The mother to child transmission (MTCT) of HIV refers to the transmission of HIV from an HIV-positive woman to her child during pregnancy, labour, delivery or breastfeeding. Maternal to child transmission (MTCT) is responsible for over $90 \%$ of all childhood infection. ${ }^{1}$ Lack of awareness regarding HIV and preventive practices may be one of the reasons behind high HIV transmission rate. Mother to child transmission of HIV is around 15 to $40 \%$ without any treatment which can be reduced to less than $5 \%$ if adequate measures taken during antenatal, intrapartum and postpartum period which includes use of ART, elective caesarian section and avoidance of breast feeding with prophylactic ART to newborn. ${ }^{2}$ This cross sectional study was done to evaluate knowledge about HIV and its transmission and prevention among pregnant women.

Reiterating India's success story on HIV/AIDS control, the HIV prevalence trend has witnessed significant decline among antenatal clinic attendees considered proxy for general population $(0.49 \%$ in 2007 to $0.35 \%$ in 2012-2013). Above evidence shows that India is on the track to achieve the global targets of 'Zero new infections and zero AIDS-related deaths'. ${ }^{3}$ This is achieved by effective voluntary testing and counseling, access to antiretroviral therapy, safe delivery practices, and the widespread availability and safe use of breast-milk substitutes.

The WHO promotes a comprehensive approach to PMTCT programs which includes;

- $\quad$ Prevention of new HIV infections among women of childbearing age

- Preventing unintended pregnancies among women living with HIV

- Preventing HIV transmission from a woman living with HIV to her baby

- Providing appropriate treatment, care and support to mothers living with HIV and their children and families 4

In 2013, WHO released updated PMTCT guidelines. ${ }^{5}$ In 2011, a global plan was launched to reduce the number of new HIV infections via MTCT by 90 percent by 2015 . $^{6}$ WHO identified 22 priority countries, with the top 10 (Angola, Botswana, Burundi, Cameroon, Chad, Côte d'Ivoire, Democratic Republic of the Congo, Ethiopia, Ghana and India) accounting for 75 percent of the global PMTCT service need. It was estimated that the effective scaling up of PMTCT interventions in these countries would prevent over 250,000 new infections annually. ${ }^{7}$

To achieve this global plan of preventing mother to child transmission, it is immortal to determine the knowledge and awareness of HIV/AIDS and mother to child transmission among women attending the antenatal clinic. The information obtained shall influence the counseling and education of patients and the community on HIV/AIDS, which, we suspect, will in turn decrease mother to child transmission of HIV/AIDS.

\section{METHODS}

A Cross sectional Descriptive study was carried out at the antenatal clinic of Chirayu medical college and hospital, Bhopal, Madhya Pradesh, India from August 2015 to January 2016. Antenatal clinics run with average total attendance of 40 per day. A pretested questionnaire was designed to assess awareness of the women about HIV/AIDS, evaluate their knowledge of possible routes of transmission particularly mother to child transmission and measures to prevent vertical transmission from mother to child (Appendix 1).

All patients who were newly booked for antenatal care in the hospital during the study period were listed at the booking visit. All the listed women were personally approached by the investigator and the nature of the study was explained to them and their consent was obtained. Only those willing to be interviewed were included in the study. A pretested interview based questionnaire was administered to all participants before they were counseled about HIV/AIDS and testing. The pregnant women were informed that answering the questionnaire is voluntary and that the information will be handled confidentially. During the course of study if patient desiring for VCT were sent for VCTC. The study protocol was cleared by the Research and ethical committees of the college.

For the descriptive aspects of the analysis, frequency distributions were generated for all categorical variables. Parameters studied include general knowledge of HIV, specific knowledge regarding MTCT, and attitude toward screening of HIV and voluntary counseling. Data were expressed as percentages and then analyzed.

\section{RESULTS}

During the study period 300 new women booked for antenatal care were contacted out of them 248 were agreed to be interviewed.

Age of participants ranged from 16 to 40 years; with $80 \%$ of participants were in between 20 to 30 years, $48 \%$ were primigravida and $51.6 \%$ were multigravida. All the subjects were married. Majority of women were educated up to secondary level $40 \%, 38 \%$ were educated up to primary level and $19 \%$ of subjects were having tertiary level education (Table 1).

Awareness and knowledge of HIV/AIDS among study population is summarized in Table 2 . Out of the study subjects $84 \%$ were heard about HIV. $16 \%$ were not even heard about HIV. The main sources of information were television $53 \%$, posters $26 \%$, and health worker $14 \%$. 
Table 1: Sociodemographic characteristics of the study population.

\begin{tabular}{|lll|}
\hline \multicolumn{2}{|c|}{ Number } & Percentage \\
\hline Age (years) & & \\
\hline $16-19$ & 20 & $08 \%$ \\
\hline $20-25$ & 120 & $48 \%$ \\
\hline $26-30$ & 80 & $32 \%$ \\
\hline$>30$ & 28 & $11 \%$ \\
\hline Parity & \\
\hline Primi & 120 & $48 \%$ \\
\hline Multi & 128 & $51.6 \%$ \\
\hline Marital status & & \\
\hline Married & 248 & $100 \%$ \\
\hline Separated & & \\
\hline Divorced & & \\
\hline Widowed & & \\
\hline Educational level & & $02 \%$ \\
\hline None & 05 & $38 \%$ \\
\hline Primary & 95 & $40 \%$ \\
\hline Secondary & 100 & $19 \%$ \\
\hline Tertiary & 48 & \\
\hline
\end{tabular}

Table 2: Awareness and knowledge of HIV/AIDS.

\begin{tabular}{|c|c|c|}
\hline & Number & Percentage \\
\hline \multicolumn{3}{|l|}{ Heard of HIV/AIDS? } \\
\hline Yes & 208 & $84 \%$ \\
\hline $\mathrm{NO}$ & 40 & $16 \%$ \\
\hline \multicolumn{3}{|l|}{ Don’t know } \\
\hline \multicolumn{3}{|l|}{ Source of information } \\
\hline $\begin{array}{l}\text { Friends, relatives, } \\
\text { neighbors }\end{array}$ & 16 & $06.4 \%$ \\
\hline \multicolumn{3}{|l|}{ Religious homes } \\
\hline Health workers & 36 & $14 \%$ \\
\hline Radio & 24 & $09.6 \%$ \\
\hline Posters & 64 & $26 \%$ \\
\hline Television & 132 & $53 \%$ \\
\hline \multicolumn{3}{|l|}{ Newspapers } \\
\hline \multicolumn{3}{|l|}{ Others (state) } \\
\hline \multicolumn{3}{|l|}{ Route of transmission } \\
\hline $\begin{array}{l}\text { sexual intercourse with } \\
\text { infected partner }\end{array}$ & 136 & $54.8 \%$ \\
\hline $\begin{array}{l}\text { sharing sharp object with } \\
\text { infected person }\end{array}$ & 108 & $43.5 \%$ \\
\hline $\begin{array}{l}\text { transfusion with infected } \\
\text { blood }\end{array}$ & 72 & $29 \%$ \\
\hline $\begin{array}{l}\text { mother to child } \\
\text { transmission }\end{array}$ & 64 & $25 \%$ \\
\hline Tattoo & 12 & $04.8 \%$ \\
\hline Don’t know & 28 & $11 \%$ \\
\hline \multicolumn{3}{|c|}{$\begin{array}{l}\text { Can an apparently healthy individual be infected } \\
\text { with HIV? }\end{array}$} \\
\hline Yes & 160 & $64 \%$ \\
\hline No & 12 & $4.8 \%$ \\
\hline Don't know & 76 & $30.6 \%$ \\
\hline
\end{tabular}

Not all of them were aware of sexual intercourse as a route of transmission only $54.8 \%$ of patients were aware of sexual intercourse as a mode of transmission. $43 \%$ were aware of sharing infected needle can transmit infection. Only $29 \%$ of patients were aware of blood transfusion as a cause of transmission. Out of study subjects only $25.8 \%$ of women were aware of mother to child transmission. $11 \%$ of subjects did not know how HIV can be transmitted. Only $4.8 \%$ of subjects were aware that HIV can transmitted by tattoo*. 64\% of women felt that an apparently healthy person can be a HIV infected person. $64 \%$ of subjects were aware that apparently healthy pregnant women can also have HIV infection. $64 \%$ of women were aware that the infected mother can transmit infection to her unborn baby. $51 \%$ were aware that transmission could occur during pregnancy, $12.9 \%$ were aware that infection can also transmitted by breastfeeding. Only $1 \%$ of the women know that HIV can transmit during vaginal delivery. 20\% of respondents believed that caesarian section also causes transmission of infection.

Table 3: Knowledge about HIV/AIDS and pregnancy.

\begin{tabular}{|c|c|c|}
\hline & Number & Percentage \\
\hline \multicolumn{3}{|c|}{ Can pregnant women be infected with HIV? } \\
\hline Yes & 160 & $64 \%$ \\
\hline No & 12 & $4.8 \%$ \\
\hline Don’t know & 76 & $30.6 \%$ \\
\hline \multicolumn{3}{|c|}{ Can mother to child transmission be prevented } \\
\hline Yes & 160 & $64 \%$ \\
\hline No & 08 & $03 \%$ \\
\hline Don’t know & 80 & $32 \%$ \\
\hline \multicolumn{3}{|c|}{ Can infected mother trans mitt infection to her child } \\
\hline Yes & 164 & $66 \%$ \\
\hline No & 20 & $08 \%$ \\
\hline Don’t know & 52 & $20.9 \%$ \\
\hline \multicolumn{3}{|c|}{$\begin{array}{l}\text { How can an infected mother transmit the infection } \\
\text { to her child }\end{array}$} \\
\hline During pregnancy & 128 & $51.6 \%$ \\
\hline Through vaginal delivery & 04 & $01 \%$ \\
\hline Through caesarean section & 20 & $08 \%$ \\
\hline Through breast feeding & 32 & $12.9 \%$ \\
\hline Don't know & 60 & $24 \%$ \\
\hline \multicolumn{3}{|c|}{$\begin{array}{l}\text { How can mother to child transmission of infection } \\
\text { be prevented }\end{array}$} \\
\hline $\begin{array}{l}\text { Antiretroviral therapy } \\
\text { during pregnancy }\end{array}$ & 76 & $30.6 \%$ \\
\hline Delivery by caesarean section & 20 & $08 \%$ \\
\hline $\begin{array}{l}\text { Giving antiretroviral } \\
\text { drugs/injections to the new- } \\
\text { born }\end{array}$ & 36 & $14 \%$ \\
\hline Avoid breast feeding & 68 & $27.4 \%$ \\
\hline Don’t know & 116 & $46.7 \%$ \\
\hline
\end{tabular}

Knowledge about HIV/AIDS and pregnancy is summarized in table $3.64 \%$ respondents believed that MTCT could be prevented. $30.6 \%$ women were aware 
that use of ART can prevent MTCT. Very few of $(08 \%)$ respondents were aware that deliveries by caesarean section can prevent MTCT. 14\% of women were aware of giving ART to new-born can also help to prevent MTCT. 27.4\% were aware of avoiding breastfeeding for preventing MTCT. $46.7 \%$ females were unaware of prevention of MTCT.

Table 4: Awareness regarding prevention and treatment.

\begin{tabular}{|c|c|c|}
\hline & Number & Percentage \\
\hline \multicolumn{3}{|c|}{$\begin{array}{l}\text { Infected person can transmit the virus to his/her } \\
\text { sexual partner(s)? }\end{array}$} \\
\hline Yes & 148 & $74 \%$ \\
\hline No & 12 & $04.8 \%$ \\
\hline Don’t Know & 40 & $16 \%$ \\
\hline \multicolumn{3}{|c|}{$\begin{array}{l}\text { Does sexual relation with multiple partner increases } \\
\text { risk of contracting HIV/AIDS? }\end{array}$} \\
\hline Yes & 192 & $77.4 \%$ \\
\hline No & 48 & $19.3 \%$ \\
\hline \multicolumn{3}{|c|}{ Do you think HIV/AIDS is preventable? } \\
\hline Yes & 148 & $74 \%$ \\
\hline No & 04 & $01.6 \%$ \\
\hline Don't know & 48 & $19.3 \%$ \\
\hline \multicolumn{3}{|c|}{$\begin{array}{l}\text { Are you aware of availability of drugs to treat AIDS } \\
\text { patients? }\end{array}$} \\
\hline Yes & 148 & $59.6 \%$ \\
\hline No & 04 & $01.6 \%$ \\
\hline Don’t know & 84 & $33 \%$ \\
\hline \multicolumn{3}{|c|}{$\begin{array}{l}\text { Does the use of condom protect against HIV } \\
\text { transmission? }\end{array}$} \\
\hline Yes & 180 & $72.5 \%$ \\
\hline No & 12 & $04.8 \%$ \\
\hline Don't know & 52 & $20.9 \%$ \\
\hline
\end{tabular}

Awareness regarding prevention and treatment of MTCT is tabulated in Table 4. Significant percentages of women (74\%) were aware of contracting infection by sexual contact with infected partner. Majority of them $(77.4 \%)$ were aware of increased risk of contracting HIV/AIDS by sexual relationship with multiple partners. $74 \%$ of females were aware that HIV/AIDS is preventable. $59.6 \%$ of women were aware of availability of ART of AIDS treatment. $72.5 \%$ of study population was aware that use of condom can protect against HIV transmission.

\section{DISCUSSION}

Present study is focused on awareness of HIV among pregnant women and their knowledge about HIV as well as MTCT. As per NFHS-3 data although the spread of HIV/AIDS is a major concern in India, only $61 \%$ of women aged $15-49$ and $84 \%$ of men aged 15-49 have heard of AIDS. Awareness about HIV and its transmission have been raised among pregnant population, but only $84 \%$ of the women in the study were heard about it, $50 \%$ were knowing transmission by sexual intercourse and sharing sharps as main routes of transmission. The main sources of information were television $(53 \%)$ and posters $26 \%$. Health worker contributed very less for their information (14\%). Findings were consistent with other studies. ${ }^{8-10}$

When asked about route of transmission, only $25 \%$ of antenatal women said MTCT is also a route of transmission but when asked about that can infected mother transmit infection to her unborn child then $66 \%$ answered yes. This indicates that more than $50 \%$ of antenatal population was aware of MTCT. $51 \%$ felt that transmission could occur during pregnancy, $12 \%$ were aware that infant could get infected through breastfeeding. Only $8 \%$ were aware that infection can occur during vaginal delivery. A study by Adeleke et al on awareness and knowledge of MTCT of HIV among mothers attending a pediatric HIV clinic in northern Nigeria also found that more than half of the respondents had no idea on MTCT; only 6 and 24\% knew cesarean section and avoiding breastfeeding, respectively, could have roles to play in MTCT. ${ }^{11}$ This pattern of poor comprehensive knowledge about MTCT of HIV has been identified by previous studies both within and outside Nigeria. $^{12,13}$

$64 \%$ of study population felt that mother to child transmission is preventable. $30 \%$ were aware of availability of Anti-retroviral treatment and $27.7 \%$ were also aware that transmission could be preventable by avoiding breastfeeding. $46 \%$ of study population was unaware of methods of prevention of MTCT. Regarding general knowledge of HIV $74 \%$ felt that infected person can transmit infection to their sexual partner. $77 \%$ felt that having sexual relationship with multiple partners also increases risk of getting infection. $72 \%$ of population knew that use of condom can prevent transmission.

\section{CONCLUSION}

Although awareness of HIV and MTCT is increased as compared to previous studies, but to achieve global plan to reduce MTCT by $90 \%$ there is still need to promote programs targeting antenatal population with emphasis on MTCT and its various methods of prevention.

Funding: No funding sources

Conflict of interest: None declared

Ethical approval: The study was approved by the Institutional Ethics Committee

\section{REFERENCES}

1. AIDS info HIV prevention: preventing mother to child transmission of HIV; 2014.

2. WHO HIV/AIDS: prevention of mother to child HIV transmission; 2014.

3. Annual report 2013-2014. Available at http://www.naco.gov.in/upload/2014\%20mslns/NAC O_English\%202013-14.pdf. 
4. WHO, PMTCT strategic vision 2010-2015: Preventing mother to child transmission of HIV to reach the UNGASS and Millennium Development Goals; 2010.

5. WHO, consolidated guidelines on the use of antiretroviral drugs; 2013.

6. UNICEF, wide political support for eliminating 90 per cent of new HIV infections in children is yielding impressive results; 2014.

7. WHO, global report; 2013.

8. Tibdewel SS, Wadhva SK. HIV/AIDS awareness among hospital employees. Indian $\mathrm{J}$ Med Sci. 2001;55:69-72.

9. Chatterjee N. AIDS-related information exposure in the mass media and discussion within social networks among married women in Bombay. India AIDS Care. 1999;11:443-6.
10. Porter SB. Public knowledge and attitudes about AIDS among adults in Calcutta. India AIDS Care. 1993;5:169-76.

11. Adeleke SI, Mukhtar-Yola M, Gwarzo GD. Awareness and knowledge of mother to child transmission of HIV among mothers attending the pediatric HIV clinic, Kano. Nigeria Ann Afr Med. 2009;8(4):210-4.

12. Abiodun MO, Ijaiya MA, Aboyeji PA. Awareness and knowledge of mother to child transmission of HIV among pregnant women. J Natl Med Assoc. 2007;99(7):758-63.

13. Harms G, Mayer A, Karcher H. Prevention of mother to child transmission of HIV in Kenya, Tanzania and Uganda. Berlin: Report of government of Tanzania PMTCT project, International coordination office; 2003:1-26.

Cite this article as: Parmar M, Aherwar R, Jawade $\mathrm{S}$. Awareness, knowledge and prevention of mother to child transmission of human immunodeficiency virus in pregnant women: a descriptive study. Int $\mathrm{J}$ Reprod Contracept Obstet Gynecol 2016;5:2215-20. 


\section{Appendix 1}

Reg No - Age- Occupation- Religion- Rural/Urban

Marital Status: i. Married ii. Separated iii. Divorced iv. widowed

Level of Education: i. none ii. Primary iii. Secondary iv. Tertiary

Economic status (per capita income) Obstetric Status Gestational age

1. Have you heard of HIV/AIDS? i. Yes ii. No iii Don`t know

- Delivery by caesarean section

2. What is the source of your information about HIV/AIDS?

- Friends, relatives, neighbors

- Religious homes

- Health workers

- Radio

- Posters

- Television

- Newspapers

- Others (state)

3. How is HIV transmitted from one person to another?

- Through sexual intercourse with infected partner
$>$ Yes
$>$ No
$>$ Don't know

- Through sharing sharp object with infected person
$>$ Yes
$>$ No
$>$ Don't know

- Through transfusion with infected blood
$>$ Yes
$>$ No
$>$ Don't know

- Through mother to child transmission
$>$ Yes
$>$ No
$>$ Don't know

- Others (state)

- Don't know

4. Can an apparently healthy individual be infected with HIV?
$>$ Yes
$>$ No
$>$ Don't know

5. Can pregnant women be infected with HIV?
$>$ Yes
$>$ No
$>$ Don't know

6. Can an infected mother transmit the infection to the child?
$>$ Yes
$>$ No
$>$ Don't know

7. How can mother to child transmission of infection be prevented?

- Antiretroviral therapy during pregnancy
$>$ Yes
$>$ No
$>$ Don't know

$>$ Yes

$>\mathrm{No}$

$>$ Don't know

- Giving antiretroviral drugs/injections to the newborn

$>$ Yes

$>\mathrm{No}$

$>$ Don't know

- Avoid breast feeding

$>$ Yes

$>\mathrm{No}$

$>$ Don't know

- Others (state)

- Don't know

8. How can an infected mother transmit the infection to her child

- During pregnancy
$>$ Yes
$>$ No
$>$ Don't know

- Through vaginal delivery
$>$ Yes
$>$ No
$>$ Don't know

- Through caesarean section

$>$ Yes

$>$ No

$>$ Don't know

- Through breast feeding

$>$ Yes

$>\mathrm{No}$

$>$ Don't know

- Others (state)

- Don't know

9. Can an infected person transmit the virus to his/her sexual partner(s)?

10. Does sexual relation with multiple partners increases risk of contracting HIV/AIDS?

11. Do you think HIV/AIDS is preventable?
$>$ Yes
$>$ No
$>$ Don't know

12. Are you aware of availability of drugs to treat AIDS patients?

$>$ Yes

$>$ No

$>$ Don't know

13. Does the use of condom protect against HIV transmission?

$>$ Yes

$>$ No

$>$ Don't know. 